\title{
Plastic Surgery Obsession: Brazil's Dr. Ivo Pitanguy Triggered It All
}

\author{
Kimberly Swartz
}

Received: 22 November 2010/ Accepted: 23 November 2010/Published online: 24 December 2010

(C) Springer Science+Business Media, LLC and International Society of Aesthetic Plastic Surgery 2010

This book provides a new look into the exciting life enjoyed by one of the greatest plastic surgeons in history. As a second-cousin-in-law of Pitanguy, the book's author, John Holzer, had unrivaled access to the surgeon's personal life.

The book begins by recounting Pitanguy's early years and the emergence of his career in plastic surgery, born of wartime innovation and harrowing experience in burn surgery. Holzer's account is accompanied by a broad historical overview of the entire field of plastic surgery. The historical reports are bolstered by interviews with wellrespected surgeons such as Daniel Baker, Sherrell Aston, Thomas Biggs, and Ernest Manders, among many other best known physicians of our time.

This introductory section of the book is slightly cursory in nature. But because we all are familiar with the work of Pitanguy, this part is presented in a novel and personal way. What follows is the most engaging part of the book. While still recounting Pitanguy's illustrious career, the remainder of the biography focuses more on his personal life, which is remarkably glamorous.
The amount of research Holzer put into the book is evidenced in the collection of minute details he shares with the reader relating to lavish Pitanguy dinner parties, including everything from the color of his wife's gowns to the guest lists of these exclusive events. Holzer also gives a firsthand account of Pitanguy's exotic private island. Yet amid all of this, Pitanguy never abandoned his busy operating and teaching schedule, something Holzer is keen to make the reader realize by constant reference to the numerous innovations Pitanguy was making throughout his career.

The extensive account of Pitanguy's social life comes at the expense of certain subjects, such as his dismissal from the American Society of Plastic and Reconstructive Surgeons, which are not given the coverage they fairly warrant.

The book itself is a quick read, akin to a gossip magazine in style but exhaustive in its scope. Ultimately, the reader is left with a greater appreciation of Pitanguy and what it took for him to become one of the biggest names in plastic surgery.

K. Swartz $(\bowtie)$

Administrator of Academic Content,

Aesthetic Plastic Surgery, Weston, USA

e-mail: kswartz@nyu.edu 